\title{
Clinical comparison of the effectiveness of 7- and 14-day intracanal medications in root canal disinfection and inflammatory cytokines
}

\author{
Frederico C. Martinho ${ }^{1}$ - Cinthya C. Gomes ${ }^{2}$ - Gustavo G. Nascimento ${ }^{3}$. \\ Ana P. M. Gomes ${ }^{1}$ - Fábio R. M. Leite ${ }^{3}$
}

Received: 17 May 2017 / Accepted: 30 May 2017 /Published online: 6 June 2017

(C) Springer-Verlag Berlin Heidelberg 2017

\begin{abstract}
Objective This clinical study compared the effectiveness of 7and 14-day intracanal medications in the reduction of bacteria/ endotoxins from primarily infected root canals and determined their antigenicity against macrophages through the levels of cytokines.

Methods Seventy-two primarily infected teeth were randomly divided into six groups according to medication and time of application: 7-day groups $=\mathrm{G} 1, \mathrm{Ca}(\mathrm{OH})_{2}+$ saline solution (SSL); $\mathrm{G} 2, \mathrm{Ca}(\mathrm{OH})_{2}+2 \%$ chlorhexidine $(\mathrm{CHX})$ gel; and $\mathrm{G} 3,2 \% \mathrm{CHX}$ gel and 14-day groups $=\mathrm{G} 4, \mathrm{Ca}(\mathrm{OH})_{2}+\mathrm{SSL}$; $\mathrm{G} 5, \mathrm{Ca}(\mathrm{OH})_{2}+2 \% \mathrm{CHX}$ gel; and G6, $2 \% \mathrm{CHX}$ gel (all groups, $n=12$ ). Bacterial and endotoxin samples were collected from root canals and inflammatory cytokines of macrophages supernatants. Culture techniques were used to determine bacterial counts and limulus amebocyte lysate (LAL) assay to quantify endotoxins. IL- $1 \beta, \mathrm{TNF}-\alpha$, and $\mathrm{PGE}_{2}$ were measured by ELISA-assay.

Results With regard to the bacterial reduction, no differences were found between all protocols tested $(p>0.05)$. The CHX
\end{abstract}

The original version of this article was revised: The name of Gustavo G. Nascimento was incorrectly presented as Gustavo N. Nascimento.

Frederico C. Martinho

Frederico.martinho@ fosjc.unesp.br

1 Department of Restorative Dentistry, Endodontic Division, São José dos Campos Dental School, State University of São Paulo - UNESP, Eng Francisco José Longo, 777, São José dos Campos, São Paulo CEP 12245-000, Brazil

2 Department of Restorative Dentistry, Endodontic Division, Fluminense Federal University (UFF), Nova Friburgo, RJ, Brazil

3 Department of Semiology, School of Dentistry, Federal University of Pelotas, Pelotas, RS, Brazil protocols (G3 and G6) exhibited the lowest effectiveness against endotoxins $(p<0.05)$. All protocols were effective in lowering the levels of IL- $1 \beta, \mathrm{TNF}-\alpha$, and $\mathrm{PGE}_{2}(p<0.05)$, with no difference between the medications tested on days 7 or 14 $(p>0.05)$. Particularly, the 7-day CHX-protocol (G3) exhibited the lowest effectiveness in lowering the levels of most cytokines compared to the 14-day protocols (G6) $(p<0.05)$.

Conclusions All the 7- and 14-day intracanal medications were effective in reducing bacteria and endotoxins as well as in lowering the levels of inflammatory cytokines, with CHX showing limited effectiveness against endotoxins. Moreover, 7-day CHX-protocol exhibited the lowest effectiveness in lowering the levels of most cytokines compared to the 14day protocols.

Clinical significance Seven-day CHX protocol is the less effective protocol and should be carefully applied by the clinician.

Keywords Calcium hydroxide $\cdot$ Chlorhexidine . Inflammatory markers $\cdot$ Endotoxin $\cdot$ Endodontic treatment

\section{Introduction}

Apical periodontitis is an inflammatory disorder of the periradicular tissue caused by bacterial infection of endodontic origin, which is characterized by periapical bone resorption [1]. Primary endodontic disease has a polymicrobial etiology, with predominance of Gram-negative anaerobic bacteria [2, 3]. This species presents lipopolysaccharides (LPSs), one of the most important inflammatory molecules present in the outer layer of its membrane [4], which can be released during multiplication or bacterial death, thus continuously stimulating the surrounding tissues even at low levels [5]. Endotoxins have been detected in $100 \%$ of the primarily infected root 
canals [6-10], with high levels being related to more severe inflammatory response in periapical tissues [8, 11, 12].

When bacteria and their toxins (e.g., LPS) present in the root canal infection egress into the periapical tissues via apical foramen, they activate immune response locally [13, 14], culminating in a very complex inflammatory disorder involving a variety of inflammatory cells [15] as well as different proinflammatory cytokines $[6,13,14]$. IL- $1 \beta$, TNF- $\alpha$, and PGE2 have been detected in periapical tissues [13, 14, 16, 17], being considered important inflammatory biomarkers in the apical disease [6-8, 13, 14].

Since bacteria and their by-products are one of the main causes of apical periodontitis, special emphasis is given to the search for an optimal root canal disinfection protocol [11, 18-20]. Although instrumentation may be assumed to be of greater importance in the clinical practice, the use of intracanal medication has been proven to optimize the root canal disinfection $[11,19,21,22]$. For this reason, a wide variety of intracanal medications have been proposed [11, 19-23].

Calcium hydroxide $\left[\mathrm{Ca}(\mathrm{OH})_{2}\right]$ is the most commonly used intracanal medication [11, 19, 20, 22-25]. Lately, chlorhexidine $(\mathrm{CHX})$ has emerged as a potential intracanal medication $[14,23,25,26]$ and suggested to be used alone or combined with $\mathrm{Ca}(\mathrm{OH})_{2}$ in a paste. Although studies have investigated the antibacterial property of $\mathrm{Ca}(\mathrm{OH})_{2}$, including $\mathrm{CHX}$ associations, the effects on immune periapical response is incipient $[13,14]$.

Different $\mathrm{Ca}(\mathrm{OH})_{2}$ pastes using inert (i.e., saline solution, propylene glycol) and activity (i.e., $\mathrm{CHX}$ gel) vehicles as well as different periods of application ( 7 or 14 days) have been proposed [11, 13, 19, 20, 23, 24]. However, in the clinical practice, a question arises on whether type of vehicle (inert or activity) and period of application ( 7 or 14 days) can influence the removal/elimination of bacteria and endotoxins from infected root canals and lower the levels of inflammatory cytokines present in apical periodontitis.

Overall, this clinical study was conducted to compare the effectiveness of 7- and 14-day intracanal medications in reducing bacteria/endotoxins from primarily infected root canals and to determine their antigenicity against macrophages through the levels of cytokines.

\section{Material and methods}

\section{Patient selection}

Seventy-two patients attending the dental school for primary endodontic treatment were randomly included in the present study. Randomization was performed with the software Excel 2011 (Microsoft Company) by a person who was not involved in this study. A detailed dental history was obtained from each patient. None of the patients reported any type of systemic disease (all healthy subjects) and those who had received antibiotic treatment during the last 3 months or who had any general disease were excluded. The Human Research Ethics Committee of the São José dos Campos Dental School (UNESP) approved the protocol describing the sample collection for this investigation, and all the volunteer patients signed an informed consent form.

All the selected teeth were single-rooted ones with pulp necrosis and apical periodontitis, with the presence of one root canal first verified in the periapical radiograph and confirmed after accessing the pulp chamber and root canal exploration. Central and lateral maxillary incisors and first and second maxillary and mandibular premolars showing a single root canal were included. All teeth with periodontal pockets deeper than $4 \mathrm{~mm}$ were excluded. None of the patients reported spontaneous pain. Teeth that could not be isolated with rubber dam were excluded. The sample size calculation was based on a previous investigation [11], and 12 patients were required for each group.

\section{Sampling procedures}

Files, instruments, and all materials used in this study were treated with $\mathrm{Co}^{60}$ gamma radiation $(20 \mathrm{kGy}$ for $6 \mathrm{~h}$ ) for sterilization and elimination of preexisting endotoxins (EMBRARAD; Empresa Brasileira de Radiação, Cotia, SP, Brazil). The method used for disinfection of the operative field had been previously described elsewhere [11]. The teeth were isolated with rubber dam and their crowns and surrounding structures were disinfected with $30 \% \mathrm{H}_{2} \mathrm{O}_{2}$ (volume/volume $[v / v]$ ) for $30 \mathrm{~s}$, followed by $2.5 \% \mathrm{NaOCl}$ for the same period of time before inactivation with $5 \%$ sodium thiosulfate. Sterility was checked by taking a swab sample from the crown surface and streaking it on blood agar plates, which were then incubated both aerobically and anaerobically.

A two-stage access cavity preparation was made without the use of water spray, but under manual irrigation with sterile/ apyrogenic saline solution and by using sterile/apyrogenic high-speed diamond bur [11]. The first stage was performed to promote a major removal of contaminants, including carious lesion and restoration. In the second stage, before entering the pulp chamber, the access cavity was disinfected according to the protocol described above. Sterility of the internal surface of the access cavity was checked as previously described and all procedures were performed aseptically. A first endotoxin sampling (baseline endotoxin sample) was obtained by introducing sterile/apyrogenic paper points (size \#15, Dentsply-Maillefer, Balaigues, Switzerland) into the full length of the canal, determined radiographically, and retained in position during $60 \mathrm{~s}$ [11]. Immediately after, the sample was placed in a pyrogen-free glass and immediately suspended in $1 \mathrm{~mL}$ of limulus amebocyte lysate (LAL) water, according to the endotoxin dosage, by using the kinetic-chromogenic LAL 
(Lonza, Walkersville, MD, USA) assay. This sampling procedure was repeated with three paper points that were pooled in a sterile tube containing $1 \mathrm{~mL}$ of Viability Medium Göteborg Agar (VMGA) transport medium for microbial cultivation (baseline bacterial sample) [11].

After accessing the pulp chamber and sampling the subsequent first endotoxin, teeth were randomly divided into six groups according to experimental intra-canal medication and time of application as follows: 7-day experimental groups = G1: calcium hydroxide $\left(\mathrm{Ca}(\mathrm{OH})_{2}\right)+$ saline solution $\left.(\mathrm{SSL})\right]$ $(n=12), \mathrm{G} 2: \mathrm{Ca}(\mathrm{OH})_{2}+2 \%$ chlorhexidine gel $(2 \% \mathrm{CHX}$ gel) $(n=12)$, and G3: $2 \%$ CHX gel $(n=12)$ and 14-day experimental groups $=\mathrm{G} 4: \mathrm{Ca}(\mathrm{OH})_{2}+\mathrm{SSL}(n=12), \mathrm{G} 5$ : $\mathrm{Ca}(\mathrm{OH})_{2}+2 \%$ CHX-gel $(n=12)$, and G6: $2 \% \mathrm{CHX}$ gel $(n=12)$.

Root canal was explored with a K-file size \#10 (DentsplyMaillefer, Ballaigues, Switzerland) with $2.5 \% \mathrm{NaOCl}$. The working length (WL) was determined with the aid of an electronic apex locator (Elements Diagnostic Unit; Sybron Endo, Orange County, CA, USA) and confirmed by radiographs. All root canals were instrumented by using the ProTaper system (Dentsply-Maillefer, Ballaigues, Switzerland) up to F2 instrument (25/.08). After the use of each instrument, a \#10 K-file was placed $1 \mathrm{~mm}$ beyond the WL to maintain patency of the apical foramen. The use of each instrument was followed by irrigation with $5 \mathrm{~mL}$ of $2.5 \% \mathrm{NaOCl}$ solution by means of a 27-gauge side-vented needle (Endo-Eze; Ultradent).

Before the second sampling after instrumentation, $\mathrm{NaOCl}$ was inactivated with $5 \mathrm{~mL}$ of sterile sodium thiosulfate at $0.5 \%$ during a $1-\mathrm{min}$ period, which was then removed with $5 \mathrm{~mL}$ of sterile/apyrogenic water. The second endotoxin and bacterial samples were obtained as previously described.

Next, the root canals were washed with $10 \mathrm{~mL}$ of saline solution and then flooded with $17 \%$ ethylenediaminetetraacetic acid (EDTA) during $3 \mathrm{~min}$ in order to neutralize $\mathrm{NaOCl}$ before application of the root canal medications. EDTA was activated by using hand K-files. Next, a final rinse with $5 \mathrm{~mL}$ of sterile/apyrogenic saline solution was performed.

The canals were then dried with sterile/apyrogenic paper points and filled with either $\mathrm{Ca}(\mathrm{OH})_{2}+\mathrm{SSL} ; 2 \%$ $\mathrm{CHX}$ gel $+\mathrm{Ca}(\mathrm{OH})_{2}$; or $2 \% \mathrm{CHX}$ gel according to the group selection. The $\mathrm{Ca}(\mathrm{OH})_{2}$ paste was freshly prepared and plugged into the canal by using Lentulo files (Malleifer-Dentsply) and the blunt end of a paper point. Care was taken to fill properly the root canal with $\mathrm{Ca}(\mathrm{OH})_{2}$ paste without any radiographically visible air bubble. The paste was condensed at the canal orifice level with the aid of a sterile cotton pellet. Another sterile cotton pellet moistened in absolute alcohol was used to remove $\mathrm{Ca}(\mathrm{OH})_{2}$ residues from the pulp chamber walls. The access cavities were properly filled with Cavit (ESPE, Seefeld, Germany) and light-cured resin (Z-250, 3 M Dental Products, St. Paul, MN, USA).
On day 7, for G1-3, and on day 14 , for G4-6, the canals were aseptically accessed under rubber dam isolation by using the protocol for disinfection described above. The medication was removed with $5 \mathrm{~mL}$ of saline solution and by carefully filing the canal with a master apical file. Next, the root canals were irrigated with $10 \mathrm{~mL}$ of saline solution. For the groups using $\mathrm{Ca}(\mathrm{OH})_{2}$, the calcium hydroxide antimicrobial activity was neutralized with $0.5 \%$ citric acid during 1 -min period, which was then removed with $5 \mathrm{~mL}$ of saline solution. Thus, for the groups with CHX gel, the chlorhexidine antimicrobial activity present in the root canal medication was inactivated with $5 \mathrm{~mL}$ of a solution containing $5 \%$ Tween 80 and $0.07 \%$ $(w / v)$ lecithin during 1-min period, which was then removed with $5 \mathrm{~mL}$ of saline solution. The final bacterial and endotoxin samplings were performed in the root canals.

Bacterial culture analysis-determination of bacterial counts (culturing procedure) The method used for culture procedures in the present study had been previously described by the author [11]. The transport media containing the root canal samples were thoroughly shaken for $60 \mathrm{~s}$ (Vortex; Marconi, Piracicaba, São Paulo, Brazil). Serial 10-fold dilutions were made up to $10^{-4}$ in tubes containing fastidious anaerobe broth (FAB; Lab M, Bury, UK). Fifty microliters of the serial dilutions were plated onto $5 \%$ defibrinated sheep blood (fastidious anaerobe agar, FAA; Lab M) by using sterile plastic spreaders to culture non-selective obligate anaerobes and facultative anaerobes. The plates were incubated at $37{ }^{\circ} \mathrm{C}$ in anaerobic atmosphere for up to 14 days. After this period, colony-forming units (CFUs) were visually quantified for each plate.

Endotoxin analysis-quantification of endotoxins (LPS) (kinetic-chromogenic LAL assay) The method used for quantification of endotoxins in the present study had been previously described by the author [11]. The kineticchromogenic LAL assay (Lonza) was used for quantification of endotoxins. Escherichia coli endotoxin was used as standard. A positive control (root canal sample contaminated with a known amount of endotoxin) was included for each sample to determine the presence or absence of interfering agents. For the test, $100 \mathrm{~mL}$ of apyrogenic water (reaction blank), five standard endotoxin solutions $(0.005-50$ endotoxin units $(\mathrm{EU}) / \mathrm{mL}$ ), root canal samples, and positive controls (each root canal sample contaminated with a known concentration of endotoxin $[10 \mathrm{EU} / \mathrm{mL}])$ were added to a 96-well apyrogenic plate. The tests were carried out in quadruplicate. The plate was incubated at $37 \pm 1^{\circ} \mathrm{C}$ for $10 \mathrm{~min}$ and placed in a KineticQCL (Lonza) reader, which was coupled to a microcomputer by means of the WinKQCL software. Next, $100 \mathrm{~mL}$ of chromogenic reagent was added to each well. After the beginning of the kinetic test, the software continuously monitored absorbance at $405 \mathrm{~nm}$ in each microplate well and automatically 
calculated the $\log / \log$ linear correlation between reaction time of each standard solution and corresponding endotoxin concentration.

Inflammatory analysis-quantification of inflammatory cytokines (ELISA assay) The amounts of IL- $1 \beta$ and TNF- $\alpha$ and PGE2 were measured by using the ELISA kit (R\&D, Minneapolis, MN). Next, standard and sample solutions were added to the ELISA well plate, which had been precoated with specific monoclonal capture antibody for IL-1 $\beta$, TNF- $\alpha$, and PGE2. After being gently shaken for $3 \mathrm{~h}$ at room temperature, the polyclonal anti-IL-1 $\beta$, anti-TNF- $\alpha$, and antiPGE2 antibodies, conjugated with horseradish peroxidase, were added to the solution and incubated for $1 \mathrm{~h}$ at room temperature. A substrate solution containing hydrogen peroxidase and chromogen was added and allowed to react for $20 \mathrm{~min}$. The levels of cytokines were assessed with a microELISA reader at $450 \mathrm{~nm}$ and normalized with standard solution. Each densitometric value, expressed as mean \pm standard deviation, was obtained from three independent experiments. Macrophages (RAW 264.7) were cultured and stimulated with $60 \mathrm{~mL}$ of root canal contents during $24 \mathrm{~h}$ in order to quantify IL- $1 \beta$, TNF- $\alpha$ and PGE2 as previously described by the authors [8].

\section{Statistical analysis}

Data were typed into a spreadsheet and the software STATA 12.0 (StataCorp., College Station, TX, USA) was used to perform the analysis. Data with non-normal distribution were $\log 10$ transformed. In order to compare bacteria, endotoxin, and cytokine levels in the initial and final stages of endodontic treatment, the paired $t$ test was used. The two-way ANOVA test was used to evaluate whether time of application and type of intracanal medication, as well as their interaction, affected significantly the results. Finally, one-way ANOVA with Tukey's post hoc test was then performed and Pearson's coefficient was used to correlate the amount of bacterial levels present in root canal infection regarding IL- $1 \beta$, TNF- $\alpha$, and $\mathrm{PGE}_{2}$. Significance level was always set at 5\% $(p<0.05)$.

\section{Results}

All patients recruited for the study completed the trial $(n=72)$. Sterility samples taken from the external and internal surfaces of the crown and its surrounding structures, tested before and after entering the pulp chamber, showed no microbial growth.

Determination of bacterial counts (culturing procedure) Culturable bacteria were found in all baseline samples of the 72 root canals investigated, ranging from $1.20 \times 10^{3}$ to $2.98 \times 10^{7}(\mathrm{CFU} / \mathrm{mL})\left(\right.$ median value $=5.26 \times 10^{5} \mathrm{CFU} /$
$\mathrm{mL})$. Regardless of the root canal medication, a significant bacterial load reduction was achieved after 7 and 14 days of intracanal medication (all, $p<0.05$ ) (Fig. 1). The chemomechanical preparation was effective is reducing $94 \%$ of bacterial load (72/72). Distribution of individual median and range of values $(\mathrm{CFU} / \mathrm{mL})$ of bacteria found before and after 7 and 14 days of intracanal treatment are shown in Table 1. Tukey's test revealed no statistically significant difference between the median percentage values of bacterial reduction achieved after all treatment protocols: 7-day intracanal medication groups $=\mathrm{G} 1\left[\mathrm{Ca}(\mathrm{OH})_{2}+\mathrm{SSL}, 99.80 \%\right] ; \mathrm{G} 2\left[\mathrm{Ca}(\mathrm{OH})_{2}\right.$ $+2 \%$ CHX gel, 99.64\%]; G3 [2\% CHX gel, 99.73\%] and 14day intracanal medication groups $=\mathrm{G} 4\left[\mathrm{Ca}(\mathrm{OH})_{2}+\mathrm{SSL}\right.$, 99.98\%]; G5 [Ca(OH) $)_{2}+2 \%$ CHX gel, $\left.99.36 \%\right]$; G6 [2\% CHX gel, 99.71\%] (all, $p>0.05$ ). Regardless of the intracanal medication, a higher number of root canals yielding negative cultures were found in all 14-day intracanal medication groups compared to the 7-day groups: 3/12 (G1), 3/12 (G2), and 1/12 (G3) for 7 days of medication and 5/12 (G4), 5/12 (G5), and 4/ 12 (G6) for 14 days of medication.

Quantification of endotoxins (LPS) (kinetic-chromogenic LAL assay) The standard curve for detection of endotoxins fulfilled the criteria of linearity of the LAL test $(r=1)$. At the baseline, the LAL assay indicated that endotoxins were detected in $100 \%$ of the root canals, with a median value of $102 \mathrm{EU} / \mathrm{mL}$ (72/72). Table 1 shows the distribution of individual median and range of values of endotoxins $(\mathrm{EU} / \mathrm{mL})$ found before and after 7 and 14 days of intracanal treatments. All 7- and 14-day intracanal medication groups were effective in reducing endotoxins in the root canal infection: 7 days of intracanal medication $=\mathrm{G} 1\left[\mathrm{Ca}(\mathrm{OH})_{2}+\mathrm{SSL}, 89.80 \%\right] ; \mathrm{G} 2$ $\left[\mathrm{Ca}(\mathrm{OH})_{2}+2 \% \mathrm{CHX}\right.$ gel, 90.05\%]; and G3 [2\% CHX gel, $79.26 \%]$ and 14 days of intracanal medication $=\mathrm{G} 4\left[\mathrm{Ca}(\mathrm{OH})_{2}\right.$ + SSL, 96.58\%]; G5 [Ca(OH) $)_{2}+2 \%$ CHX gel, 97.19\%]; and

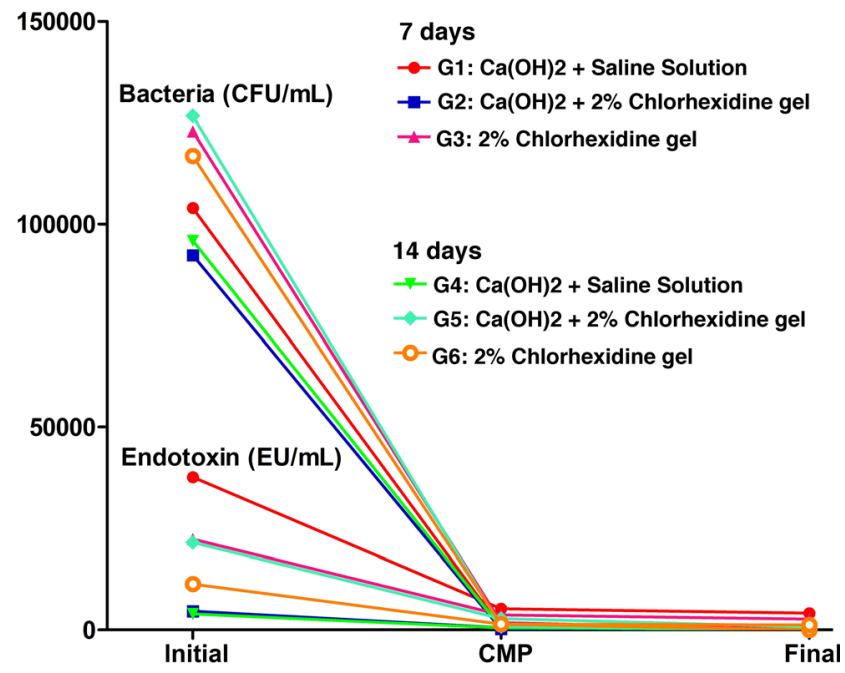

Fig. 1 Bacterial and endotoxin reduction during different steps of endodontic treatment 
Table 1 Distribution of individual median and range of values of bacteria $(\mathrm{CFU} / \mathrm{mL})$ and endotoxins $(\mathrm{EU} / \mathrm{mL})$ found before and after 7 and 14 days of intracanal medications treatment

\begin{tabular}{|c|c|c|c|c|}
\hline \multirow{3}{*}{$\begin{array}{l}\text { 7-day root canal } \\
\text { medication groups }\end{array}$} & \multicolumn{4}{|c|}{ 7-dayroot canal medication groups } \\
\hline & \multicolumn{2}{|l|}{ Bacteria $(\mathrm{CFU} / \mathrm{mL})$} & \multicolumn{2}{|c|}{ Endotoxin $(\mathrm{EU} / \mathrm{mL})$} \\
\hline & Before treatment & $\begin{array}{l}\text { After } \\
\text { treatment }\end{array}$ & $\begin{array}{l}\text { Before } \\
\text { treatment }\end{array}$ & $\begin{array}{l}\text { After } \\
\text { treatment }\end{array}$ \\
\hline $\mathrm{G} 1=\mathrm{Ca}(\mathrm{OH})_{2}+\mathrm{SSL}$ & $\begin{array}{l}9.50 \times 10^{5} \\
\left(1.98 \times 10^{3}-2.88 \times 10^{6}\right)\end{array}$ & $\begin{array}{l}2.05 \times 10^{2} \\
\left(0-5.8 \times 10^{2}\right)\end{array}$ & $\begin{array}{l}101.60 \\
(21.64-257)\end{array}$ & $\begin{array}{l}9.63 \\
(0.032-9.38)\end{array}$ \\
\hline $\begin{array}{l}\mathrm{G} 2=\mathrm{Ca}(\mathrm{OH})_{2}+2 \% \mathrm{CHX} \\
\quad \text { gel }\end{array}$ & $\begin{array}{l}3.20 \times 10^{6} \\
\left(1.20 \times 10^{3}-3.84 \times 10^{6}\right)\end{array}$ & $\begin{array}{l}4.07 \times 10^{2} \\
\left(0-2.40 \times 10^{3}\right)\end{array}$ & $\begin{array}{l}92.45 \\
(24.78-224.2)\end{array}$ & $\begin{array}{l}7.85 \\
(0.019-10.05)\end{array}$ \\
\hline $\mathrm{G} 3=2 \% \mathrm{CHX}$ gel & $\begin{array}{l}1.98 \times 10^{5} \\
\left(1.96 \times 10^{3}-2.70 \times 10^{6}\right)\end{array}$ & $\begin{array}{l}5.78 \times 10^{2} \\
\left(0-4.39 \times 10^{3}\right)\end{array}$ & $\begin{array}{l}102.17 \\
(19.23-221.5)\end{array}$ & $\begin{array}{l}18.56^{*} \\
(2.67-20.1)\end{array}$ \\
\hline $\begin{array}{l}\text { 14-day root canal } \\
\text { medication groups }\end{array}$ & \multicolumn{2}{|l|}{ Bacteria $(\mathrm{CFU} / \mathrm{mL})$} & \multicolumn{2}{|c|}{ Endotoxin $(\mathrm{EU} / \mathrm{mL})$} \\
\hline $\mathrm{G} 4=\mathrm{Ca}(\mathrm{OH})_{2}+\mathrm{SSL}$ & $\begin{array}{l}9.75 \times 10^{5} \\
\left(1.98 \times 10^{3}-2.98 \times 10^{7}\right)\end{array}$ & $\begin{array}{l}2.15 \times 10^{2} \\
\left(0-1.80 \times 10^{2}\right)\end{array}$ & $\begin{array}{l}114.58 \\
(15.63-201.40)\end{array}$ & $\begin{array}{l}5.74 \\
(0.020-4.8)\end{array}$ \\
\hline $\begin{array}{l}\mathrm{G} 5=\mathrm{Ca}(\mathrm{OH})_{2}+2 \% \\
\quad \mathrm{CHX} \text { gel }\end{array}$ & $\begin{array}{l}1.26 \times 10^{6} \\
\left(1.80 \times 10^{3}-3.89 \times 10^{6}\right)\end{array}$ & $\begin{array}{l}2.34 \times 10^{2} \\
\left(0-1.60 \times 10^{2}\right)\end{array}$ & $\begin{array}{l}98.73 \\
(29.62-241.19)\end{array}$ & $\begin{array}{l}4.32 \\
(0.064-8.72)\end{array}$ \\
\hline $\mathrm{G} 6=2 \% \mathrm{CHX}$ gel & $\begin{array}{l}1.16 \times 10^{5} \\
\left(1.95 \times 10^{3}-4.70 \times 10^{6}\right)\end{array}$ & $\begin{array}{l}3.70 \times 10^{2} \\
\left(0-7.20 \times 10^{2}\right)\end{array}$ & $\begin{array}{l}104.52 \\
(22.94-252.50)\end{array}$ & $\begin{array}{l}19.21 * \\
(1.472-32.4)\end{array}$ \\
\hline
\end{tabular}

G6 [2\% CHX gel, 78.64\%] (all, $p<0.05$ ). All CHX protocols (G3 and G6) exhibited the lowest effectiveness against endotoxins $(p<0.05)$ (Table 1$)$. Moreover, no differences were found between $\mathrm{Ca}(\mathrm{OH})_{2}$ medications after 7 and 14 days of intra-canal treatment $(p>0.05)$.

Quantification of inflammatory cytokines (ELISA assay) At the baseline, IL- $1 \beta, \mathrm{TNF}-\alpha$, and $\mathrm{PGE}_{2}$ were detected in all samples $(72 / 72)$ with the following values, respectively,
$628.30,148.09$, and $118.33 \mathrm{pg} / \mathrm{mL}$. Table 2 shows the distribution of individual median and range values $(\mathrm{pg} / \mathrm{mL})$ of inflammatory cytokines found in the interstitial fluid sampled from periapical tissues before and after intracanal medication. All 7-day (G1-3) and 14-day (G4-6) intracanal treatments were found to be effective in lowering the levels of IL-1 $\beta$, TNF- $\alpha$, and $\mathrm{PGE}_{2}(p<0.05)$ (Fig. 2). No significant differences were found between intracanal medications tested in the 7- or 14-day treatment protocol ( $p>0.05)$ (Fig. 2a, b).

Table 2 Distribution of individual median and range values $(\mathrm{pg} / \mathrm{mL})$ of inflammatory cytokines before and after intracanal medications treatment

\begin{tabular}{|c|c|c|c|c|c|c|}
\hline & \multicolumn{2}{|l|}{ IL1-beta } & \multicolumn{2}{|l|}{ TNF-alpha } & \multicolumn{2}{|l|}{ PGE2 } \\
\hline & Before treatment & After treatment & Before treatment & After treatment & Before treatment & After treatment \\
\hline & \multicolumn{6}{|c|}{7 days of intracanal medication treatment } \\
\hline $\mathrm{G} 1=\mathrm{Ca}(\mathrm{OH})_{2}+\mathrm{SSL}$ & $\begin{array}{l}610.10 \\
(422.83-890.03)\end{array}$ & $\begin{array}{l}197.01 \\
(147.99-276.16)\end{array}$ & $\begin{array}{l}147.20 \\
(98.06-214.03)\end{array}$ & $\begin{array}{l}49.60 \\
(33.34-69.54)\end{array}$ & $\begin{array}{l}124.85 \\
(56.78-214.03)\end{array}$ & $\begin{array}{l}40.23 \\
(18.16-75.13)\end{array}$ \\
\hline $\mathrm{G} 2=\mathrm{Ca}(\mathrm{OH})_{2}+2 \% \mathrm{CHX}$ gel & $\begin{array}{l}579.96 \\
(352.34-872.3)\end{array}$ & $\begin{array}{l}199.92 \\
(123.31-296.58)\end{array}$ & $\begin{array}{l}136.81 \\
(98.07-223.77)\end{array}$ & $\begin{array}{l}48.13 \\
(33.32-71.6)\end{array}$ & $\begin{array}{l}112.75 \\
(52.3-276.81)\end{array}$ & $\begin{array}{l}35.48 \\
(15.76-83.04)\end{array}$ \\
\hline $\mathrm{G} 3=2 \%$ CHX gel & $\begin{array}{l}610.79 \\
(344.8-980)\end{array}$ & $\begin{array}{l}207.76 \\
(124.12-288.09)\end{array}$ & $\begin{array}{l}134.53 \\
(96.05-223.96)\end{array}$ & $\begin{array}{l}59.36 \\
(30.73-112.04)\end{array}$ & $\begin{array}{l}123.64 \\
(48.9-211.27)\end{array}$ & $\begin{array}{l}60.73 \\
(15.48-103.94)\end{array}$ \\
\hline $\mathrm{G} 4=\mathrm{Ca}(\mathrm{OH})_{2}+\mathrm{SSL}$ & $\begin{array}{l}14 \text { days of intraca } \\
655.70 \\
(478.90-904.43)\end{array}$ & $\begin{array}{l}\text { al medication treat } \\
192.46 \\
(148.45-325.59)\end{array}$ & $\begin{array}{l}153.95 \\
(97.04-265.68)\end{array}$ & $\begin{array}{l}48.03 \\
(30.32-85.70)\end{array}$ & $\begin{array}{l}109.29 \\
(54.31-245.69)\end{array}$ & $\begin{array}{l}32.48 \\
(16.36-72.26)\end{array}$ \\
\hline $\mathrm{G} 5=\mathrm{Ca}(\mathrm{OH})_{2}+2 \% \mathrm{CHX}$ gel & $\begin{array}{l}555.15 \\
(322.45-967.49)\end{array}$ & $\begin{array}{l}185.59 \\
(99.95-328.94)\end{array}$ & $\begin{array}{l}149.52 \\
(98.67-234.32)\end{array}$ & $\begin{array}{l}47.70 \\
(28.67-73.22)\end{array}$ & $\begin{array}{l}127.14 \\
(52.39-274.53)\end{array}$ & $\begin{array}{l}38.48 \\
(14.96-85.79)\end{array}$ \\
\hline $\mathrm{G} 6=2 \% \mathrm{CHX}$ gel & $\begin{array}{l}522.10 \\
(336.50-960.47)\end{array}$ & $\begin{array}{l}219.81 \\
(102.77-330.96)\end{array}$ & $\begin{array}{l}150.09 \\
(96.89-225.49)\end{array}$ & $\begin{array}{l}45.16 \\
(28.49-70.46)\end{array}$ & $\begin{array}{l}128.53 \\
(55.34-216.37)\end{array}$ & $\begin{array}{l}42.97 \\
(17.85-67.61)\end{array}$ \\
\hline
\end{tabular}


Fig. 2 Effectiveness of 7- (a) and 14-day (b) intracanal medications protocols on lowering the levels of inflammatory cytokines (IL$1 \beta$, TNF- $\alpha$, and PGE2). Different letters $p<0.05$
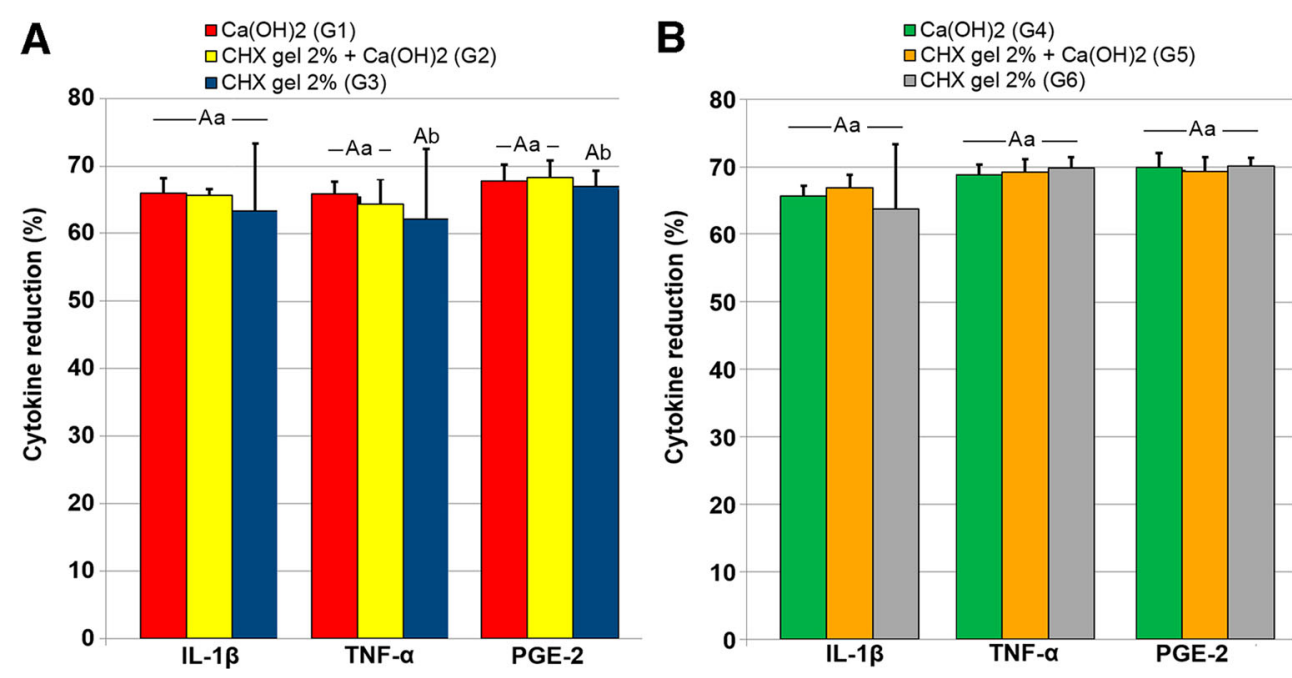

Particularly, the 7-day CHX-protocol (G3) showed the lowest effectiveness in lowering most cytokines levels compared to the 14-day protocols $(p<0.05)$ (Fig. 2a, b). Thus, positive correlations were found between higher bacterial counts and higher levels of IL-1 $\beta$, TNF- $\alpha$, and $\mathrm{PGE}_{2}$ (all, $p<0.05$ ).

\section{Discussion}

In the present study, all initial samples were found to be positive for presence of bacteria with CFUs per root canal, ranging from $10^{3}$ to $10^{7}$, which is comparable to previous studies $[11,21,23]$. The chemo-mechanical preparation was the most responsible for the reduction of $94 \%$ of bacterial load present in infected root canals. The use of chemo-mechanical preparation with intracanal medication contributed significantly to improving the reduction of bacterial contents from infected root canals, with CFUs per root canal ranging from 0 to $10^{3}$.

Regardless of the type of vehicle for $\mathrm{Ca}(\mathrm{OH})_{2}$ pastes, that is, inert ( $\mathrm{SSL}$ ) or active $(\mathrm{CHX}), \mathrm{Ca}(\mathrm{OH})_{2}$ medications exhibited a high antimicrobial activity [11, 20, 21, 27]. Particularly, $\mathrm{Ca}(\mathrm{OH})_{2}+$ SLL was highly effective in reducing bacteria load, with median values of 99.80 and $99.98 \%$ after 7 and 14 days of treatment, respectively. Despite this high effectiveness, special concerns exist regarding the use of $\mathrm{Ca}(\mathrm{OH})_{2}$ with an inert vehicle (i.e., SSL), namely: Concerns regarding type of infection - (a) bacterial arrangement, such as biofilms and palisade colonization, may dampen its lethal effects [28]; (b) bacterial resistance [22, 29]; and (c) long-lasting infectious process with high bacterial density with large number of bacterial species and higher propagation of bacteria to dentin tubules and ramifications; Concerns regarding intracanal disinfection: (a) $\mathrm{Ca}(\mathrm{OH})_{2}$ has a limited antibacterial spectrum that does not affect all members of the endodontic microbiota [22]; (b) $\mathrm{Ca}(\mathrm{OH})_{2}$ has bacterial lethal effects only by direct contact, being clinically limited by the root canal anatomy
[29]; (c) $\mathrm{Ca}(\mathrm{OH})_{2}$ has low solubility and diffusibility, making it difficult to reach a rapid and significant increase in $\mathrm{pH}$ to eliminate bacteria present in biofilms, dentinal tubules, tissue remnants, and anatomic variations; (d) physicochemical properties of this substance may limit its effectiveness in disinfecting the root canal system after a short-term use; (e) $\mathrm{pH}$ levels in long-time dressings; and (f) high buffering ability of the dentin, which controls $\mathrm{pH}$ changes and thereby reduces its antimicrobial effectiveness [30].

In an attempt to sidestep these limitations, the association of $\mathrm{Ca}(\mathrm{OH})_{2}$ with other antibacterial substances has been proposed $[11,21,24,31,32]$. Because the wide broad spectrum of CHX against both Gram-positive and Gram-negative bacteria, yeasts, facultative anaerobes, and anaerobic bacteria [25], including their long-term resistance to infection, this substance emerges as an alternative medication to $\mathrm{Ca}(\mathrm{OH})_{2}$, as well as in combination with $\mathrm{Ca}(\mathrm{OH})_{2}$ as an activity vehicle. Particularly, when tested as an alternative intracanal medication, it was found to be effective in reducing bacterial load in 99.73 and $99.71 \%$ after 7 and 14-day treatment protocols, respectively. The high antimicrobial activity of CHX found in the present study is in accordance with previous investigations [24, 26,33]. When tested as an activity vehicle for $\mathrm{Ca}(\mathrm{OH})_{2}$, such a combination resulted in a reduction of 99.64 and $99.36 \%$, respectively. Up until now, there is no consensus among the studies investigating the antimicrobial effectiveness of $\mathrm{Ca}(\mathrm{OH})_{2}$ mixed with $\mathrm{CHX}[11,21$, 31, 32]. Although some studies showed that the antimicrobial effects of $\mathrm{Ca}(\mathrm{OH})_{2}$ are significantly increased when adding CHX to a paste $[32,34]$, others have shown no significant increase in such an activity $[11,31]$. Chemically, the combined use of $\mathrm{CHX}$ with $\mathrm{Ca}(\mathrm{OH})_{2}$ in the root canal may generate excessive reactive oxygen species, which can potentially kill various root canal pathogens [32]. In vitro studies reported that the efficacy of $\mathrm{Ca}(\mathrm{OH})_{2}$ is significantly reduced when mixed with CHX because of the changes in the alkalinity of calcium hydroxide [31, 32]. 
In the present study, LAL assay has detected endotoxins in $100 \%$ of the root canals, thus agreeing with previous investigations [6-11]. Because of their high inflammatory potential to periapical tissues, special attention has been given for the removal of endotoxins from endodontic infections [9, 11, 24]. The LAL assay employs a serine protease catalytic coagulation cascade that is activated by endotoxin. Factor $\mathrm{C}(\mathrm{FC})$, the first component in the cascade, is a protease zymogen activated by endotoxin binding. Downstream, this pathway activates a pro-clotting enzyme into a clotting enzyme (coagulogen coagulin). The chromogenic LAL assay (QCL or KQCL) uses the synthetic peptide-pNA substrate, which is cleaved by the clotting enzyme, imparting a yellow color to the solution. The strength of the yellow color (determined at an optical density $(\mathrm{OD})=405 \mathrm{~nm}$ ) resulting from the chromogenic LAL substrate is correlated with the endotoxin concentration.

In this study, although 2\% CHX gel exhibited low effectiveness against endotoxins, $\mathrm{Ca}(\mathrm{OH})_{2}$ exhibited a high endotoxin detoxifying activity, regardless of the type of vehicle tested, that is, inert (SSL) or active (CHX) and of time of application (7 or 14 days of therapy). The limited effectiveness of CHX against endotoxins [10] and the high endotoxin detoxifying activity of $\mathrm{Ca}(\mathrm{OH})_{2}$ medications found in the present study are in accordance with the literature $[11,23,35]$. The ability of $\mathrm{Ca}(\mathrm{OH})_{2}$ in neutralizing LPS molecule is attributed to its capacity to cleave ester-linked hydroxy fatty acids [36].

Our findings have revealed the presence of IL- $1 \beta$, TNF- $\alpha$, and PGE2 in all samples investigated. IL- $1 \beta$, TNF- $\alpha$, and PGE2 are commonly found in apical periodontitis disease $[6-8,13,14,16,17,37]$, being closely related to the development of clinical features and bone destruction $[6-8,13,14]$. Particularly, IL-1 $\beta$ and TNF- $\alpha$ are known to initiate and augment subsequent inflammatory cascades, leading to tissue destruction [17], whereas PGE2 seems to be directly and indirectly implicated with most of the inflammatory and destructive changes in apical lesions, such as vasodilatation and increased vascular permeability and collagen degradation $[7$, 37]. All 7- and 14-day treatment protocols were effective in lowering the levels of IL- $1 \beta$, TNF- $\alpha$, and PGE2, with no differences between the medications tested. The benefits of $\mathrm{Ca}(\mathrm{OH})_{2}$ and $\mathrm{CHX}$ gel intracanal medications in preventing the increase of inflammatory biomarkers in the periapical tissue have been demonstrated elsewhere [13, 14]. Particularly, the 7-day CHX-protocol (G3) exhibited the lowest effectiveness in lowering the levels of most cytokines compared to the 14-day protocols. Essentially, the limited ability of CHX to significantly lower the levels of inflammatory biomarkers is addressed elsewhere [14]. The association of CHX-gel with $\mathrm{Ca}(\mathrm{OH})_{2}$ medication has currently brought benefit in lowering the levels of inflammatory cytokines. Barthel et al. [38] and Safavi and Nichols [36] showed that bacterial LPS, when treated with $\mathrm{Ca}(\mathrm{OH})_{2}$, has its biological properties changed, thus indirectly affecting the TNF- $\alpha$ and PGE2 secretion.
Considering the positive correlations between higher bacterial counts and higher levels of inflammatory cytokines found in this study, together with the concept that the equilibrium between root canal pathogens and anti-infective defense mechanism initiates involution of inflammatory process, one might speculate whether the decrease in inflammatory cytokines is attributed not only to the anti-inflammatory activity of medications but also to their antimicrobial activity (by switching off the influence of bacterial contents).

In conclusion, all the 7- and 14-day intracanal medication protocols were effective in reducing bacteria and endotoxins as well as in lowering the levels of inflammatory cytokines, with CHX showing limited effectiveness against endotoxins. Moreover, 7-day CHX-protocol exhibited the lowest effectiveness in lowering the levels of most cytokines compared to the 14-day protocols.

\section{Compliance with ethical standards}

Conflict of interest Frederico C. Martinho has no conflict of interest. Gustavo N. Nascimento has no conflict of interest. Fábio R. M. Leite has no conflict of interest. Cinthya C. Gomes has no conflict of interest. Ana P. M. Gomes has no conflict of interest.

Funding This work was supported by FAPESP, CAPES, and CNPq.

Ethical approval The Human Research Ethics Committee of the São José dos Campos Dental School (UNESP) approved the protocol describing the sample collection for this investigation. All procedures performed in this study involving human participants were in accordance with the ethical standards of the institutional and/or national research committee.

Informed consent Informed consent was obtained from all individual participants included in the study.

\section{References}

1. Nair PN (2006) On the causes of persistent apical periodontitis: a review. Int Endod J 39:249-281. doi:10.1111/j.1365-2591.2006. 01099.x

2. Santos AL, Siqueira JF Jr, Rôças IN, Jesus EC, Rosado AS, Tiedje JM (2011) Comparing the bacterial diversity of acute and chronic dental root canal infections. PLoS One 6:e28088. doi:10.1371/ journal.pone. 0028088

3. Siqueira JF Jr, Alves FR, Rôças IN (2011) Pyrosequencing analysis of the apical root canal microbiota. J Endod 37:1499-1503. doi:10. 1016/j.joen.2011.08.012

4. Schein B, Schilder H (1975) Endotoxin content in endodontically involved teeth. J Endod 1:19-21. doi:10.1016/S0099-2399(75) 80244-5

5. Garcia de Aquino S, Manzolli Leite FR, Stach-Machado DR, Francisco da Silva JA, Spolidorio LC, Rossa C Jr (2009) Signaling pathways associated with the expression of inflammatory mediators activated during the course of two models of experimental periodontitis. Life Sci 84:745-754. doi:10.1016/j.1fs.2009.03. 001

6. Martinho FC, Chiesa WM, Leite FR, Cirelli JA, Gomes BP (2012) Correlation between clinical/radiographic features and 
inflammatory cytokine networks produced by macrophages stimulated with endodontic content. J Endod 38:740-745. doi:10.1016/j. joen.2012.02.021

7. Martinho FC, Chiesa WM, Leite FR, Cirelli JA, Gomes BP (2011) Antigenicity of primary endodontic infection against macrophages by the levels of PGE(2) production. J Endod 37:602-607. doi:10. 1016/j.joen.2010.12.005

8. Martinho FC, Chiesa WM, Leite FR, Cirelli JA, Gomes BP (2010) Antigenic activity of bacterial endodontic contents from primary root canal infection with periapical lesions against macrophage in the release of interleukin-1beta and tumor necrosis factor alpha. $\mathrm{J}$ Endod 36:1467-1474. doi:10.1016/j.joen.2010.06.012

9. Martinho FC, Chiesa WM, Marinho AC, Zaia AA, Ferraz CC, Almeida JF, Souza-Filho FJ, Gomes BP (2010) Clinical investigation of the efficacy of chemomechanical preparation with rotary nickel-titanium files for removal of endotoxin from primarily infected root canals. J Endod 36:1766-1769. doi:10.1016/j.joen. 2010.08.019

10. Gomes BP, Martinho FC, Vianna ME (2009) Comparison of $2.5 \%$ sodium hypochlorite and $2 \%$ chlorhexidine gel on oral bacterial lipopolysaccharide reduction from primarily infected root canals. J Endod 35:1350-1353. doi:10.1016/j.joen.2009.06.011

11. Xavier ACC, Martinho FC, Chung A, Oliveira LD, Jorge AO, Valera MC, Carvalho CA (2013) One-visit versus two-visit root canal treatment: effectiveness in the removal of endotoxins and cultivable bacteria. J Endod 39:959-964. doi:10.1016/j.joen.2013. 04.027

12. Horiba N, Maekawa Y, Abe Y, Ito M, Matsumoto T, Nakamura H (1991) Correlations between endotoxin and clinical symptoms or radiolucent areas in infected root canals. Oral Surg Oral med Oral Pathol 71:492-495

13. Tavares WL, de Brito LC, Henriques LC, Teles FR, Teles RP, Vieira LQ, Ribeiro Sobrinho AP (2012) Effects of calcium hydroxide on cytokine expression in endodontic infections. J Endod 38:13681371. doi:10.1016/j.joen.2012.06.036

14. Tavares WL, de Brito LC, Henriques LC, Oliveira RR, Maciel KF, Vieira LQ, Sobrinho AP (2013) The impact of chlorhexidine-based endodontic treatment on periapical cytokine expression in teeth. $\mathrm{J}$ Endod 39:889-892. doi:10.1016/j.joen.2013.02.005

15. Marton IJ, Kiss C (2014) Overlapping protective and destructive regulatory pathways in apical periodontitis. J Endod 40:155-163. doi:10.1016/j.joen.2013.10.036

16. Barkhordar RA, Hussain MZ, Hayashi C (1992) Detection of interleukin-1 beta in human periapical lesions. Oral Surg Oral med Oral Pathol 73:334-336

17. Unemori EN, Ehsani N, Wang M, Lee S, McGuire J, Amento EP (1994) Interleukin-1 and transforming growth factor-alpha: synergistic stimulation of metalloproteinases, PGE2, and proliferation in human fibroblasts. Exp Cell res 210:166-171. doi:10.1006/excr. 1994.1025

18. Rôças IN, Neves MA, Provenzano JC, Siqueira JF Jr (2014) Susceptibility of as-yet-uncultivated and difficult-to-culture bacteria to chemomechanical procedures. J Endod 40:33-37. doi:10. 1016/j.joen.2013.07.022

19. Rôças IN, Siqueira JF Jr (2010) Identification of bacteria enduring endodontic treatment procedures by a combined reverse transcriptase-polymerase chain reaction and reverse-capture checkerboard approach. J Endod 36:45-52. doi:10.1016/j.joen.2009.10. 022

20. Vera J, Siqueira JF Jr, Ricucci D, Loghin S, Fernandez N, Flores B, Cruz AG (2012) One- versus two-visit endodontic treatment of teeth with apical periodontitis: a histobacteriologic study. J Endod 38:1040-1052. doi:10.1016/j.joen.2012.04.010

21. Siqueira JF Jr, Guimaraes-Pinto T, Rôças IN (2007) Effects of chemomechanical preparation with $2.5 \%$ sodium hypochlorite and intracanal medication with calcium hydroxide on cultivable bacteria in infected root canals. J Endod 33:800-805. doi:10. 1016/j.joen.2006.11.023

22. Siqueira JF Jr, de Uzeda M (1996) Disinfection by calcium hydroxide pastes of dentinal tubules infected with two obligate and one facultative anaerobic bacteria. J Endod 22:674-676. doi:10.1016/ S0099-2399(96)80062-8

23. Vianna ME, Horz HP, Conrads G, Zaia AA, Souza-Filho FJ, Gomes BP (2007) Effect of root canal procedures on endotoxins and endodontic pathogens. Oral Microbiol Immunol 22:411-418. doi:10. 1111/j.1399-302X.2007.00379.x

24. Oliveira LD, Carvalho CA, Carvalho AS, Alves Jde S, Valera MC, Jorge AO (2012) Efficacy of endodontic treatment for endotoxin reduction in primarily infected root canals and evaluation of cytotoxic effects. J Endod 38:1053-1057. doi:10.1016/j.joen.2012.04. 015

25. Gomes BP, Sato E, Ferraz CC, Teixeira FB, Zaia AA, Souza-Filho FJ (2003) Evaluation of time required for recontamination of coronally sealed canals medicated with calcium hydroxide and chlorhexidine. Int Endod J 36:604-609

26. Siqueira JF Jr, Paiva SS, Rôças IN (2007) Reduction in the cultivable bacterial populations in infected root canals by a chlorhexidinebased antimicrobial protocol. J Endod 33:541-547. doi:10.1016/j. joen.2007.01.008

27. Rôças IN, Siqueira JF Jr (2011) In vivo antimicrobial effects of endodontic treatment procedures as assessed by molecular microbiologic techniques. J Endod 37:304-310. doi:10.1016/j.joen.2010. 11.003

28. Siqueira JF Jr, De Uzeda M, Fonseca ME (1996) A scanning electron microscopic evaluation of in vitro dentinal tubules penetration by selected anaerobic bacteria. J Endod 22:308-310. doi:10.1016/ S0099-2399(96)80265-2

29. Byström A, Claesson R, Sundqvist G (1985) The antibacterial effect of camphorated paramonochlorophenol, camphorated phenol and calcium hydroxide in the treatment of infected root canals. Endod Dent Traumatol 1:170-175

30. Portenier I, Haapasalo H, Rye A, Waltimo T, Ørstavik D, Haapasalo M (2001) Inactivation of root canal medicaments by dentine, hydroxylapatite and bovine serum albumin. Int Endod J 34:184-188

31. Siqueira JF Jr, Rôças IN, Lopes HP, Magalhães FA, de Uzeda M (2003) Elimination of Candida albicans infection of the radicular dentin by intracanal medications. J Endod 29:501-504. doi:10. 1097/00004770-200308000-00003

32. Gomes BP, Vianna ME, Sena NT, Zaia AA, Ferraz CC, de Souza Filho FJ (2006) In vitro evaluation of the antimicrobial activity of calcium hydroxide combined with chlorhexidine gel used as intracanal medicament. Oral Surg Oral med Oral Pathol Oral Radiol Endod 102:544-550. doi:10.1016/j.tripleo.2006.04.010

33. Mohammadi Z, Abbott PV (2009) The properties and applications of chlorhexidine in endodontics. Int Endod J 42:288-302. doi:10. $1111 / \mathrm{j} .1365-2591.2008 .01540$

34. Evans MD, Baumgartner JC, Khemaleelakul SU, Xia T (2003) Efficacy of calcium hydroxide: chlorhexidine paste as an intracanal medication in bovine dentin. J Endod 29:338-339. doi:10.1097/ 00004770-200305000-00005

35. Tanomaru JM, Leonardo MR, Tanomaru Filho M, Bonetti Filho I, Silva LA (2003) Effect of different irrigation solutions and calcium hydroxide on bacterial LPS. Int Endod J 36:733-739

36. Safavi KE, Nichols FC (1993) Effect of calcium hydroxide on bacterial lipopolysaccharide. J Endod 19:76-78. doi:10.1016/ S0099-2399(06)81199-4

37. Shimauchi H, Takayama S, Miki Y, Okada H (1997) The change of periapical exudate prostaglandin E2 levels during root canal treatment. J Endod 23:755-758

38. Barthel CR, Levin LG, Reisner HM, Trope M (1997) TNF-alpha release in monocytes after exposure to calcium hydroxide treated Escherichia coli LPS. Int Endod J 30:155-159 